\title{
Myth, collective trauma and war in Serbia: a cultural-
}

\section{hermeneutical appraisal}

\author{
By Daniel Šuber (University of Konstanz)
}

This paper explores the close relationship between mythical narrative, collective trauma and their repercussions on the Serbian population since the mid-1980s. It is argued that Serbia's particular cultural-historically inherited frame of perception provided a fertile seedbed for Milošević to successfully launch a policy of re-traumatization and thus establish widespread consent to his war policy among the population. Other cultural factors that might have contributed to broad approval of Milošević's policy will be reflected on. Drawing on recently coined concepts like 'cultural trauma' and 'cultural fear', a specifically cultural-sociological perspective on the subject will be outlined.

The following remarks are concerned with the relation between mythical thinking, historical trauma and war in Serbia. Due to the complexity of this question, this essay argues on different theoretical and empirical levels. I will have to start from an elaboration of the supposition that the Serbian perspective on its 'ethno-genesis', national identity and its role during the Balkan Wars since the 1990s is distorted by a particular frame of perception which dates back to an event that occurred in 1389. I argue that around the 'event' of the legendary 'Battle of Kosovo', a particular set of interpretive figures and cultural narratives has been set up, which was not only transmitted into the present but also played a manifest part in the scenes that surrounded the break-up of Yugoslavia. It is a separate task to mark the historical settings and circumstances under which those cultural ideas could eventually embody the 'habits of the Serbian heart' - to take up a concept adopted by Meštrović (1993). Finally, I can only provide a few illustrations of the modes in which the domain of individual action is affected by the prevalence of mythical figurations. Methodological and conceptual issues regarding the challenges and limits of a cultural approach towards the subject shall be reflected in the subtext of my contribution.

\section{Myth and method}

The main feature which renders the case of Serbia an imperative and interesting subject for cultural study is the oft quoted inter-relatedness between myth and politics. Anthropologists have been fascinated by the enigmas of mythical thinking ever since the discipline's birth. However, they took pains to account for the perseverance of mythical beliefs in modern societies as one can clearly sense, for instance, in Durkheim who, according to Mary Douglas, remained obsessed with a typical rationalist bias about the status of knowledge in modern societies (Douglas 1993:xi). However, his disciple Maurice Halbwachs became the herald for the 'Collective Memories Studies', which has turned into a major scientific industry during the past decades. One of its leading theorists, Jan Assmann, recently summarised it thus: 
"myth is the most important medium for "imagination" of community' (Assmann 1992:42). Although the relevance and crucial impact of allegedly pre-modern images in contemporary societies has been theoretically acknowledged, the process of exploration of the mnemo-technical devices and historical contexts under which mythical narratives become refuelled with meaning is currently taking place. Symptomatically, the quoted verdict — which confirms the central role of the mythical past for the recent political occurrences in Serbia-has rarely been the subject of a cultural scientific verification. Rather, an explanation of the break-up of Yugoslavia still seems to be the domain of political scientists, whose studies - not dissimilar to 'journalistic' accounts - concentrate on short-term factors like the global political context, the role of single political actors, or Yugoslavia's economic crisis in the 1980s. Thus, my work is directed at approaching a cultural interpretation of the interplay between a set of mythical narratives connected to the 'event' of the Kosovo Battle, historical experiences, and their consequences on political consciousness at the level of the individual.

What is mythical about Serbian society, anyway? An unprepared scientist could assume that the anthropologist would need to set up his or her specific instruments in order to eventually obtain a glance into the mythical past in contemporary Serbia. In contrast to this, my initial steps into the 'field' were immediately thwarted by a stereotypical reaction on the side of my supposed 'informants'. Almost anybody I talked to about my endeavour raised severe doubts, to put it euphemistically, as to whether an undistorted 'understanding' of the Serbian self-image and attitude towards their 'other' could be attained by non-Serbs. Mattijs van de Port has coined a term for this underlying attitude according to which 'it takes a Serb to know a Serb': namely 'obstinate otherness' (1999:7). Anyway, this experience constituted the entrypoint into the world I originally set out for. 'Obstinate otherness' relates back to the particular self-positioning of Serbs within the global-historical landscape. It can only be understood against the background of a complex narrative framework that consists in a variety of, at times even contradictory, units. The habit of excluding oneself from the rest of the world is not restricted to a specific realm, neither is it an exclusively political description. Rather, this argumentative pattern is reiterated in a multitude of social-cultural contexts ranging from sports to religion. A positive way to put it would be to maintain that the Serbs share a very definite image of their cultural and national identity. Before I attempt to disentangle this quandary, I should present some illustrations of the phenomenon.

If we recollect the average reaction of Serbian citizens during the NATO bombings of 2000, we encounter an excessive and widespread instance of a radical split between 'us' and 'them', where 'them', in fact, signified 'the rest of the world'. Jasminka Udovički has provided befitting remarks on the 'xenophobic sense of isolation' (2000:1) among the Serbs. This is also at the root of the oft recited identification of the Serbs as the 'Jews of the Balkans', thereby alluding to the historical fate that the Jews have suffered. While the political mythology of the Serbs envisions them to be - as the former president of the Communist League of Serbia and political mentor of Slobodan Milošević once put it-'out of history' (Stambolić 1996:18), there is also the notion that Serbia is the 'heart of Europe' proper. In the sketch presented below, we will be confronted with paradoxical subtexts that are transferred in the various narratives. Most significant is the intricate amalgamation of the notions of shame/guilt or victimhood/heroism that shines through in the cited examples. It will be 
demonstrated that a blurring of these dichotomies already pertains to the early telling of the Battle of Kosovo.

A cultural-sociological perspective must systematically account for the narrative schema linked to the Kosovo Legend as a 'social fact' and 'reality sui generis'- to phrase it with Durkheim (1982:54). For the same reasons, I view any explanation as ill-fated which neglects the concrete social-historical circumstances under which myths become imbued with political significance. Oevermann (2001:60-61), the founder of the 'objective hermeneutics' approach, understood that such phenomena were only immediately accessible to the social scientist and typically operative from behind the consciousness of actors. On the other hand, the effects were traceable through a variety of objectifications and manifestations in everyday life, Oevermann continues. From this perspective, interview analyses would only constitute a 'last resort' (ibid:62). For my purposes, it seems appropriate to trace the footprints of myth-saturated narratives in the domain of everyday action by focusing systematically on miscellaneous areas of cultural production, ranging from arts and education to politics and sports. Such a multidimensional approach can be derived from Georg Simmel's (1997) sociology of modernity, which ferreted out the influence of rationalisation in areas that traditionally were deemed ultimately impregnable.

\section{The Kosovo narratives}

A closer look at the history of transmission of the Kosovo narratives would reveal the dynamics and adaptability of mythical narratives, a characteristic which is critical to fathom for any cultural account. I can only give a short illustration of the inherent logic underlying the semantic composition of the Kosovo myth.

Today, the Serbs recollect the Kosovo Battle in 1389 as a heroic fight against the Turks, which they not only lost, but which held the germ of what was to spring up from that defeat, namely a five centuries long period under Ottoman supremacy. However, this is not the end of the story and, even less, its beginning. The only fact that seems to be confirmed is that nothing reliable can be said about what actually occurred on June, $15^{\text {th }} 1389$. Characteristically, just who won the battle remains uncertain and debatable until the present. Also, the earliest narratives of the Battle of Kosovo differ significantly from contemporary variations. At first, the Serbs interpreted the battle as a victory over the encroaching Ottomans. Very soon after the event, the 'process of "legendizing" Kosovo' (Bogert 1991:178) was born, predominantly carried out by Serbian clerics. Subsequently, the story was reframed corresponding to Biblical-Christological role-models and the battle itself was reconstructed and represented as a fateful loss of the Serbs. The main themes were the following:

(a) The idea of martyrdom. This is represented by Czar Lazar, who led the Serbian troops into the battle. Accordingly, on the eve of the battle he saw himself confronted by the alternative to either die in fighting and, therefore, save his nation, or to withdraw and survive. His 'deal with God' offered him resurrection in the 'Heavenly kingdom' in exchange for his earthly existence. This plot was later adopted in the figure of Miloš Obilić, the character that, according to the folk-tales, killed the Ottoman Sultan Murat during the battle and who was immediately beheaded by the enemy. The main lesson, in the mind of the inventors, that the Serbs had to learn from this representation of 
the Kosovo event was that sacrifice was a heroic option, which secured the persistence of the nation in the 'Heavenly kingdom'. Thus, military defeat and subjection could eventually be reinterpreted as a moral victory. Furthermore, this plot carried the most important motif of constant insurrection against the Turks, who had to be punished for the sake of the ancestors' blood that they had spilled.

(b) The idea of betrayal. The heroic story of Miloš was supplemented by his antithesis which was embodied by the figure of Vuk Branković. The legend reads that on the eve of the battle, the latter accused Miloš of a planned betrayal of Lazar to whom both were sons-in-law. The next day, however, it turned out to be Branković who fled the battlefield while Miloš fulfilled his oath and sacrificed his life. The moral of this story was that there had been discord and betrayal among the Serbs, which had doomed the nation to fall. Thus, the slogan 'Only unity can save the Serbs' (Samo sloga srbina spasava) became the catch phrase for the Serbs, also symbolised in the national emblem by the slogan's four Cyrillic 'Cs' in each corner, with the double-headed eagle in the middle.

(c) The idea of the chosen people. This is tightly coupled with the image of the covenant with God that the Serbs committed themselves to through Lazar's decision for the 'Heavenly kingdom'. The Serbs depict their national identity as a gift from God which was exclusively granted to them (Čolović 2002:70). Moreover, they were the only people who understood that it took death and sacrifices for the maintenance of this supreme status. Conclusively, the mythical narrative that underlies the Serbian national identity is ultimately structured after a heroic code.

On numerous historical occasions when the Serbs were facing military conflicts and hardships, their leaders referred to these narratives to recall a 'glorious tradition' and encourage resistance. It can be concluded that the purveyors of the Kosovo narrative seemed to be quite aware of the cathartic effect that Aristotle attributed to dramatic story-telling.

\section{Myth, history and collective trauma}

How can we account for the fact that the Kosovo narrative survived Tito's austere politics of anti-nationalism and 'forced amnesia', and eventually contributed significantly to the disruption of the idea of a united Yugoslav nation? Recent cultural studies have exploited the Freudian concept of 'trauma' to adopt it to the explanation of sudden, unexpected outbursts of collective violence. Miroslav Hadžić has scrutinized the strategy of the Communist leaders and the various societal institutions who systematically exploit 'the prevention of catharsis and the suppression of traumas' (2000:513) for the sake of their own dominance. It is right at this point that the historical processes have to be carefully taken into consideration. Western observers often tend to neglect the frangible ground upon which the Socialist Republic of Yugoslavia was built. The national project had to settle an explosive set of tensions between the various ethnic groups inherited from World War II. In particular, the Serbs had to ward off attacks that were aimed at their complete expulsion, launched by factions of German, Italian, Croatian and Albanian Fascists from different geographical areas. The notion of collective trauma reckons with the 
observation that traumatic events can be suppressed by means of political repression, as that fostered by the Titoist regime, and may only reveal their potential decades after the incident actually occurred. There is a Serbian proverb that captures the tension between present and past involved in traumatic experience: 'We can forgive, but never forget'. If there is any significance in the concept of 'embodied memory', then it must apply to the way that historical traumas are transmitted over long periods of time without having recourse to public representation.

It has been no secret to scientific observers that the most apparent collective experience that can be associated with a collective trauma in the Balkan area is expulsion. An evidence of its bearing on the subjects can only vaguely be gained from the daily news on television. Other sources convey that scenarios of mass expulsion have regularly been accompanied by high numbers of suicide action. Additionally, the unknown number of those who resisted leaving their hometowns, even under urgent threat of life, is supposedly high. Cultural collective traumas must thus be linked to the phenomenon of 'cultural fear' that has recently been adopted by anthropologists also for Balkan societies (Povrzanivić Frykman 2001). In the history of Serbia, the experience of expulsion is, once again, closely linked to the field of Kosovo which until today is regarded as the Serbian motherland. Thus, it is only relatively exaggerated to state that the end of Yugoslavia and the seeds of the Balkan wars of the 1990s were actually sown at Kosovo, although it had only been the locus of military action since 1998. It was not only the stage that Milošević had chosen for his open revolt, in 1987, against the communist doctrine that suppressed any nationalist and separatist activity. Well before this, the alleged sufferings of the Serbs living at Kosovo became the trigger for a reappraisal of the 'Serbian question' among intellectuals, clerics and politicians. Ever since Milošević played his nationalist card, the Serbian population has become the subject of a neatly planned public policy of 'nationalisation' and 're-traumatisation' in virtually all areas of social life. Since this story has been told exhaustively, ${ }^{1}$ I will confine myself to the quest for the effects that the mobilisation of suppressed traumatic experiences had on individuals and collective behaviour.

The main feature that characterises a mythological mode of perception has long been recognised as the blurring of the distance between past and present. The strategy of the Milošević regime can be discerned as a policy of 'forced remembrance' that appealed to the historically inherited cultural fears and, thus, supported the retreat to traditional ways of 'problem-solving'. Thereby, the new stories that were spread among the population through the media machinery all followed the simple but innately habituated pattern of the Kosovo narrative: the threat of being wiped out of the homeland. Victor Turner's concept of 'emplotment' (1981:149) pertains to the generative energies that epic narrative genres, when applied by political leaders, can exert on the lives of a population. For our special case it may be summarised thus: 'people adjusted to a life of semi-war' (Marković 2000:600). The 'sense of the "nowness" of history' (Blagojević 2000:230) that was engendered through this process amazingly caused the historical gap between 'Kosovo' and the current wars in Bosnia and Croatia to dwindle, as can be felt in the statement of a soldier who said: 'We are living history right now, it's not just something that happened in the past' (Judah 1997:18), or even by a distinguished Serbian historian who articulated it in this

\footnotetext{
${ }^{1}$ For a detailed picture see Popov (2000a), or for a summary view see Šuber (2004).
} 
way: 'Kosovo is not some imaginary legend of the past, but a real historical destiny that continues today' (Bogdanović 1999:4).

\section{Some 'elective affinities'}

In the rest of this paper, I will try to explore the seemingly simplistic image of the Serbia of the 1990s as a traumatised, myth-entangled society by hinting at observations drawn from a variety of social-cultural fields which display an 'elective affinity' to my hypothesis. The concept of 'elective affinity' (Weber 2002:89) does not propose a causal or immediate correlation between phenomena, but expresses an ideal-typical, 'meaningfully related' (in German: sinnhaft adäquat) link.

I want to refer to two different instances that demonstrate the prevalence of a mythically distorted frame of perception among the Serbian population. Both stupendously capture the myth-induced momentum of 'fusion' (Alexander 2006) of past and present and the inability, or at least unconcern, to adopt an outside perspective. The first example draws on a documentary movie set up by the Serbian filmmaker Želimir Žilnik in 1992, during the heights of the Bosnian War. His intention was to capture the reactions of pedestrians in the streets of Belgrade when being confronted with the 'resurrected' Tito. The perfectly dressed-up actor was sent through the city centre accompanied by a camera team. The filmed material documented a wide range of reactions from the side of the respondents. The actor was cursed as a traitor and instigator of the current state of Serbia's misery, as well as bestowed with flowers. At another point, the crowd launched into a traditional chant arm in arm with their former president. The general readiness, or rather, urge to engage in a serious discussion about the history of Serbia since Tito's death in 1980 abounded among respondents of all generations. The young director Žilnik summarized the impression that he got from this 'experiment' as follows: 'The common people have lost touch with reality. Everything you tell them through the media they absorb like a sponge' (Judah 1997:136).

Another interesting mode of everyday behaviour can be obtained from Ivan Čolović's portrayal of Serbian football-hooligans since the outbreak of war (2002:259-286). On the basis of his finding that supporters of the prominent Red Star club were especially susceptible to engaging in volunteer military guards, some of which were responsible for the most malicious atrocities during the war period, Colovic concluded that this diagnosis ran counter to any established social psychological axiom. The received wisdom until then had taken it for granted that ritualised forms of violence exerted a prophylactic and cathartic effect, which channelled naturally endowed aggressive human instincts. In the case of Serbian football fans, who literally went from the stadium straight to the Bosnian battlefields, the discrimination between 'ritual war' and 'real war' did not apply.

The Serbian sociologist Nebojša Popov has hinted at some culturally inherited predispositions of Serbs to display a somewhat fatalistic attitude towards actively striving for catharsis of traumatic burdens. He even believes that 'the syndrome of the authoritarian personality is more prevailing in Yugoslavia than anywhere else in the world' (2000b:98). The crucial fount for this particular condition is detected in the lack of success of implementation of classical modern notions of individuality and subjectivity during the historical process of ethno-genesis. Therefore, he infers, the average Serb would not see the benefit of developing a personality and a society at all. 
This deficiency, according to Popov, gives the reason for why 'an investigation of traumas and the search for catharsis belong to a parallel history which remains hidden for most' (ibid:86).

Cultural scientists have recently applied the distinction between a 'culture of shame' and a 'culture of guilt', which can help to shed some light on the cultural gap between Western and Eastern patterns of modernisation that Popov has hinted at. In this account, Serbia would have to be depicted as an instance of a culture of shame, in which society is typically perceived as the central authority. In turn, individual actors will refrain from developing an evaluative faculty on their own. Psychological investigations have confirmed an interconnection between traumatisation and shame. James Gilligan has recently concluded that 'shame is the central motive for collective as well as individual violence' (2003:1162). Drawing from the German context, Aleida Assmann and Ute Frevert have likewise worked out an 'affinity between cultures of shame and militarized societies' (Assmann and Frevert 1999:90). These depictions can induce the conclusion that a fatalistic attitude towards politics, which must be asserted even for the present Serbian society, ${ }^{2}$ was thus not only due to a temporal state of traumatisation that has been evoked by public and media policy since the $1980 \mathrm{~s}$, but is also related to a certain pattern of state-society relations typically wielded by communist and socialist systems. If we recall that political nationalism, following social-scientific interpretations, allows for one typical reaction among others towards a state of fear that occurs in ambivalent situations, the resulting picture might add a little to an understanding of why " "the return of the suppressed" occurred among the Serbian people in a dramatic, but not cathartic way' (Popov 2000b:102).

\section{References}

Alexander, J.C. 2006. Cultural pragmatics: social performance between ritual and strategy. In Social Performance. Symbolic Action, Cultural Pragmatics, and Ritual (eds) J.C. Alexander et al., 29-89. Cambridge: Cambridge University Press.

Assmann, A. and U. Frevert. 1999. Geschichtsvergessenheit-Geschichtsversessenheit. Vom Umgang mit Deutschen Vergangenheiten nach 1945 [Forgotten PastObsession with the Past. Dealings with the German Past since 1945]. Stuttgart: Deutsche Verlagsanstalt.

Assmann J. 1992. Frühe Formen politischer Mythomotorik. Fundierende, kontrarepräsentistische und revolutionäre Mythen [Early forms of political mytho-motoric: foundational, contra-representational and revolutionary myths]. In Revolution und Mythos [Revolution and Myth](eds) J. Assmann and D. Harth, 39-61. Frankfurt am Main: Fischer.

Blagojević, M. 2000. The migrations of Serbs from Kosovo during the 1970s and 1980s: trauma and/or catharsis. In The Road to War in Serbia; Trauma and Catharsis (ed.) N. Popov, 212-243. Budapest: Central European University Press.

\footnotetext{
${ }^{2}$ One need only hint at the particulars that occurred with Serbia's presidential elections in 2002, when all three run-offs failed the criterion of $50 \%$ participation, to learn that politics is still much discredited amongst the Serbian population.
} 
Bogdanović, D. 1999. The Kosovo question: past and present. In Old Serbia and Albanians (ed.) Historical Institute of Serbian Academy of Arts and Sciences. Belgrade: Serbian Academy of Arts and Sciences.

Bogert, R. 1991. Paradigm of defeat or victory? The Kosovo myth vs. the Kosovo covenant in fiction. In Kosovo. Legacy of a Medieval Battle (eds) W.S. Vucinich and T. A. Emmert, 173-188. Minneapolis: University of Minnesota.

Čolović, I. 2002. The Politics of Symbols in Serbia: Essays in Political Anthropology. London: Hurst \& Company.

Douglas, M. 1993. Implicit Meanings: Essays in Anthropology. London: Routledge.

Durkheim, E. 1982. The Rules of Sociological Method. New York: Free Press.

Gilligan, J. 2003. Shame, guilt, and violence. Social Research 70(4), 1149-1180.

Hadžić, M. 2000. The army's use of trauma. In The Road to War in Serbia: Trauma and Catharsis (ed.) N. Popov, 509-534. Budapest: Central European University Press.

Judah, T. 1997. The Serbs: History, Myth and the Destruction of Yugoslavia. New Haven: Yale University Press.

Kusturica, E. 1995. L'art et la manière. Emir Kusturica sur Underground. Cahiers de Cinéma 492(June), 67-71.

Marković, Z. 2000. The nation: victim and vengeance. In The Road to War in Serbia: Trauma and Catharsis (ed.) N. Popov, 587-607. Budapest: Central European University Press.

Meštrović, S.G. et al. 1993. Habits of the Balkan Heart. Social Character and the Fall of Communism. College Station: Texas A\&M University Press.

Oevermann, U. 2001. Die Struktur sozialer Deutungsmuster. Versuch einer Aktualisierung. Sozialer Sinn 1, 35-81.

Popov, N. (ed.) 2000a. The Road to War in Serbia: Trauma and Catharsis. Budapest: Central European University Press.

- 2000b. Traumatology of the party state. In The Road to War in Serbia: Trauma and Catharsis (ed.) N. Popov, 81-108. Budapest: Central European University Press.

Povrzanivić Frykman, M. 2001. Kultur und Angst. Über den Kriegsalltag [Culture and fear: war and everyday life]. In Kroatische Volkskunde/Ethnologie in den Neunzigern. Ein Reader [Ethnology in Croatia of the Nineties: A Reader](eds) J. Čapo Žmegač et al., 291-315. Wien: Verlag des Instituts für Europäische Ethnologie.

Simmel, G. 1997. Simmel on Culture. Selected Writings. London: Sage.

Stambolić, I. 1996. Interview. Frankfurter Rundschau No. 40:18, 16 February.

Šuber, D. 2004. Kollektive Erinnerung und nationale Identität in Serbien. Zu einer kulturalistischen Interpretation des Anfangs vom Ende Jugoslawiens [Collective memory and national identity in Serbia. Towards a cultural interpretation of the beginning of the end of Yugoslavia]. In Tätertrauma. Nationale Erinnerungen im Öffentlichen Diskurs [Trauma of Perpetrators. 
National Memories in Public Discourse](eds) B. Giesen and C. Schneider, 347-379. Konstanz: University of Konstanz Press.

Turner, V. 1981. Social dramas and stories about them. In On Narrative (ed.) W.J.T. Mitchell, 137-164. Chicago: University of Chicago Press.

Udovički, J. 2000. Introduction. In Burn This House: The Making and Unmaking of Yugoslavia (eds) J. Udovički and J. Ridgeway, 1-10. Durham NC: Duke University Press.

Van de Port, M. 1999. 'It takes a Serb to know a Serb.' Uncovering the roots of obstinate otherness in Serbia. Critique of Anthropology 19(1), 7-30.

Weber, M. 2002. The Protestant Ethic and the Spirit of Capitalism. Los Angeles: Roxbury.

Žižek, S. 1995. Multiculturalism, or the cultural logic of multinational capitalism. New Left Review 22(5), 28-51.

\section{About the author}

Daniel Šuber, born 1973, is a sociologist at the Department of History and Sociology at the University of Konstanz. He works in the fields of cultural theory and philosophy of the social sciences. He also specialises in topics concerning a culturalsociological interpretation of the recent Balkan Wars. To contact him, please write to: Daniel.Suber@uni-konstanz.de 